\title{
Analysis of genetic diversity in four Sudanese provenances of Balanites aegyptiaca (L.) Del. based on random amplified polymorphic DNA (RAPD) marker
}

\author{
Sawsan A. B. Freigoun, Tahani Y. Elagib* and Elamin Y. A. Raddad \\ Agricultural Research Corporation (ARC), Biotechnology and Biosafety Research Center (BBRC), Khartoum, Shambat, \\ Sudan. \\ Received 26 March, 2020; Accepted 4 June, 2020

\begin{abstract}
Balanites aegyptiaca (L.) Del. (Heglig) is a multipurpose tree with considerable potential. The wide range of environments under which it is growing suggests high pattern of variation among and within locations. The scrutiny was undertaken to assess genetic diversity among and within four geographical genotypes of Heglig growing naturally in four different regions of Sudan based on their seed performance using random amplified polymorphic DNA (RAPD) markers. The DNA was extracted from dried leaf materials and subjected to PCR using ten primers. A total of 57 bands were scored and 42 were polymorphic with polymorphism level ranging from 50 to $87.5 \%$ and a mean of $71.7 \%$. Cluster analysis using NTSYS-PC software, showed three main clusters. The dissimilarity values ranged between 77 and $93 \%$. Effective gene flow among the three populations of Obied, Damazin and Gedaref and limited gene flow with Genaina was observed. Populations of $B$. aegyptiaca from different provenances were confirmed to have significant genetic diversity. Results indicate that RAPD could be efficiently used for studying genetic variation of $B$. aegyptiaca. The study recommends that local provenances of $B$. aegyptiaca should be properly conserved and immediate efforts to be made to widen the genetic base through research and collection from other regions.
\end{abstract}

Key words: Balanites aegyptiaca, random amplified polymorphic DNA (RAPD), marker, genetic variation, DNA, Sudan.

\section{INTRODUCTION}

Balanites aegyptiaca (L.) Del. (Zygophyllaceae), commonly known as desert date, is a multipurpose tree or spiny shrub with considerable potential. The plant is mainly distributed in the Middle East and Africa. Natural selection, genetic drift and gene flow collectively affect the genetic diversity of populations and result in promoting or hampering local and range-wide adaptation (Magri et al., 2006; Liepelt et al., 2009). Genetic diversity among and within individuals or populations can be determined using morphological traits and molecular markers. Molecular markers have proven to be valuable tools in the characterization and evaluation of genetic

${ }^{*}$ Corresponding author. E-mail: tahani_3@yahoo.com.

Author(s) agree that this article remain permanently open access under the terms of the Creative Commons Attribution License 4.0 International License 


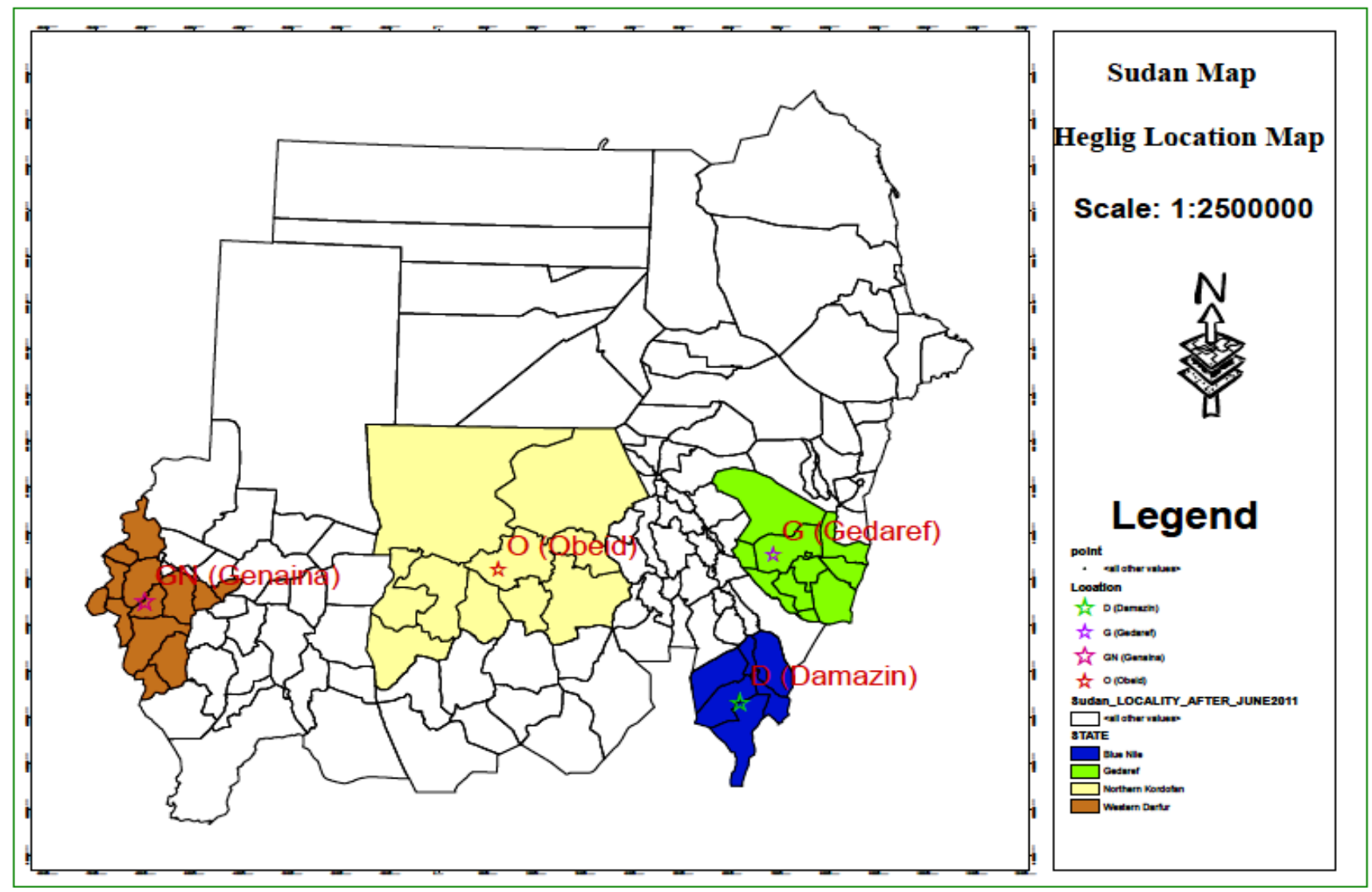

Figure 1. Location of the investigated Balanites aegyptiaca provenances collected from different regions of Sudan.

diversity within species (Nejia et al., 2007; Muchigi et al., 2008; Missihoun et al., 2015; Khamis et al., 2017). The preference of a molecular marker system should be conciliated between consistency and simplicity of analysis, low cost, statistical rule, and assurance of exposing polymorphisms.

Various types of molecular markers have been developed to investigate the genetic variation of plants (Idrees and Irshad, 2014) and forest trees in the past few decades (Mulcahy et al., 1993). Random amplified polymorphic DNA (RAPD) markers have been used extensively in analyzing genetic diversity (Garacia et al., 1998; Artyukova et al., 2004; Sureja et al., 2006; Guerra et al., 2010). It is a simple, reliable, speed and relatively low cost, straight forward technique to apply and the number of loci that can be examined is unlimited. RAPD markers have generally been used for the detection of genetic variation within and among populations in several plant species without the need for detailed knowledge of DNA (Holsinger et al., 2002; Wei et al., 2008; Zarek, 2009). Recently RAPD analysis of PCR- amplified DNA regions have been used to detect DNA variations for taxonomic purposes, particularly at the intra- and interspecific levels, the genotype stability of species and others (Abkenar et al., 2004; Liesebach and Gotz, 2008;
Ibrahim et al., 2010; Rahman and Al Munsur, 2009; Agbidinoukoun et al., 2017).

The wide range of environmental conditions under which $B$. aegyptiaca is growing suggests high pattern of variation among and within locations (Elfeel, 2010) and was reflected in a very wide inconsistency in its morphology and products (Abasse et al., 2011). At present, very little is known about genetic variation in this species and base line information are needed to initiate conservation strategies. The aim of this study was to determine the current state of genetic diversity and to assess the level of genetic variation based on molecular variation within and between populations of $B$. aegyptiaca growing naturally in different geographical regions by using RAPD markers.

\section{MATERIALS AND METHODS}

\section{Plant materials}

Four different provenances within the natural habitats of $B$. aegyptiaca were selected, namely, Genaina (GN), Obied (O), Damazin (D) and Gedarif (G) (Figure 1 and Table 1). Ten trees (families) within (D) and (G) and eight trees within (O) and (GN) provenances were marked at least $150 \mathrm{~m}$ a part. Seeds from each 
Table 1. Provenance data for Balanites aegyptiaca seed sources used in this study.

\begin{tabular}{ccccc}
\hline Location & Lat. N & Long. E & Soil type & Mean annual rainfall $(\mathbf{m m})$ \\
\hline GN & $13^{\circ} 27^{\prime}$ & $22^{\circ} 27^{\prime}$ & Sand & $500-600$ \\
$\mathrm{O}$ & $13^{\circ} 16^{\prime}$ & $30^{\circ} 27^{\prime}$ & Sand & $300-400$ \\
$\mathrm{D}$ & $11^{\circ} 81^{\prime}$ & $33^{\circ} 86^{\prime}$ & Clay & $800-1000$ \\
$\mathrm{G}$ & $14^{\circ} 03^{\prime}$ & $35^{\circ} 40^{\prime}$ & Clay & $600-700$ \\
\hline
\end{tabular}

Table 2. The sequence of the ten RAPD primers that showed amplification.

\begin{tabular}{cll}
\hline No. & Name & Sequence \\
\hline 1 & A00 & 5'-ATC AGC GCA CCA-3' \\
2 & A06 & 5'-ACT GGC CGA GGG-3' \\
3 & OPA-13 & 5'- CAGCACCCAC-3' \\
4 & OPB-07 & 5'- GGTGACGCAG-3' \\
5 & OPC-11 & 5'- AAAGCTGCGG-3' \\
6 & OPO-02 & 5'- ACACACGCTG-3' \\
7 & OPO-07 & 5'- CAGCACTGAC-3' \\
8 & OPU-03 & 5'-CTA TGC CGA C-3' \\
9 & OPU-16 & 5'-CTG CGC TGG A-3' \\
10 & OPZ-04 & 5'- AGGCTGTGCT-3' \\
\hline
\end{tabular}

family were collected separately and planted in the nursery. Fresh leaves from each tree per provenance were collected, placed in plastic and sent to Biotechnology and Biosafety Research Center of Agricultural Research Corporation (ARC) of Sudan, where they were washed with distilled water and dried.

\section{DNA extraction and DNA quality determination}

DNA extraction was carried out according to Ferreira and Grattapaglia's (1998) protocol modified for $M$. brauna because highest DNA concentration and good quality were obtained. The dried leaf tissue were placed in $2 \mu \mathrm{L}$ microtube milled using a mortar and pestle. Genomic DNA was isolated using a cationic hexadecyltrimethylammonium bromide (CTAB) extraction buffer, $700 \mu \mathrm{L}$ extraction buffer was added to each samples and samples were incubated at $65^{\circ} \mathrm{C}$ for $30 \mathrm{~min}$, with occasional shaking. Chloroform/isoamylalcohol (24:1, vol:vol, $700 \mu \mathrm{L})$ was added to each microtube after cooling for $5 \mathrm{~min}$. to remove proteins then shaken vigorously and left to stand for $5 \mathrm{~min}$. at room temperature. Then the solution was centrifuged at $13,000 \mathrm{rpm}$ for $7 \mathrm{~min}$. The supernatant was pipetted into a new microtube, and two-third the volume of $95 \%$ ice-cold isopropanol was added and allowed to precipitate at $20^{\circ} \mathrm{C}$ for $12 \mathrm{~h}$. Pellet DNA was obtained by centrifugation at $13,000 \mathrm{rpm}$ for $10 \mathrm{~min}$. by pouring off the top aqueous solution, leaving the precipitated DNA at the bottom of the tube. The pellet was washed first with $1 \mathrm{~mL}$ cold $70 \%$ ethanol, then cold $90 \%$ ethanol air dried. The DNA pellet was then resuspended in $50 \mu \mathrm{L} 1 \mathrm{xTE}$ buffer $(50 \mu \mathrm{L})$.

DNA quality and concentration were evaluated on a $0.8 \%$ agarose gel. The DNA samples were kept in $\left(-20^{\circ} \mathrm{C}\right)$ until used.

\section{RAPD genotyping}

Twenty six random RAPD primers were tested for initial screening; among them only 10 primers successfully generated clear and reliable amplification products (Table 2 ). The ten primers which showed reproducible amplicons compromise eight Operon Technology, (USA) from groups $\mathrm{A}, \mathrm{B}, \mathrm{C}, \mathrm{O}$ and $\mathrm{Z}$ and $2 \mathrm{~A}$ primer group intra- and interspecific variation were used for further analysis of all individuals.

Amplification reaction optimization was performed. The total volume of each reaction was $20 \mu \mathrm{L}$ containing $1 \mu \mathrm{L}$ genomic DNA, $4 \mu \mathrm{L}$ master mix ready to load containing $12.5 \mathrm{MgCl}_{2}$ (Solis Biodyne) which contains a component of buffer, $1 \cup$ Taq polymerase, and $0.2 \mathrm{mM}$ dNTPs, $0.5 \mu \mathrm{L}$ RAPD primer, and the final volume was adjusted to $20 \mu \mathrm{L}$ using double distill water.

Amplification conditions were adjusted according to the methodology proposed by Williams et al. (1990). The thermocycler (Biometra) was programmed for one initial denaturation step of 5 min at $95^{\circ} \mathrm{C}$ and denaturation in $94^{\circ} \mathrm{C}$ for 1 min primer annealing temperature for $1 \mathrm{~min}$ was done based on primer group and $2 \mathrm{~min}$ at $72^{\circ} \mathrm{C}$ for extension. The annealing step up to extension step was repeated for 40 cycles and final step for $5 \mathrm{~min}$ at $72^{\circ} \mathrm{C}$ for the final extension. The resulting DNA fragments from the amplification were separated by electrophoresis in $2 \%$ agarose gel for $90 \mathrm{~min}$, and then transferred to solution containing $0.2 \mu \mathrm{g} / \mathrm{mL}$ ethidium bromide for staining for $30 \mathrm{~min}$. The gels were visualized on transilluminator (Viberlourmat, Torcy company- France) in UV light and photographed.

\section{Statistical analysis}

The DNA amplification pattern obtained after amplification of the 36 genotypes was scored on the basis of presence (1) or absence (0) of amplicons on agarose gels. Clear, unambiguous and reproducible bands recovered through different techniques were considered for scoring. Each band was considered a single locus. Band size was estimated by comparing with 100 bp ladder (Solis Biodyne) using Gel Works 1D advanced gel documentation system 
M

GN $\quad$ D $\quad$ O $\quad$ G

M

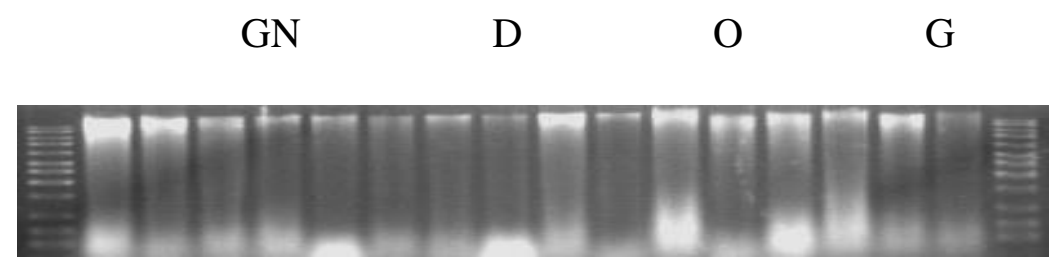

OPO-07

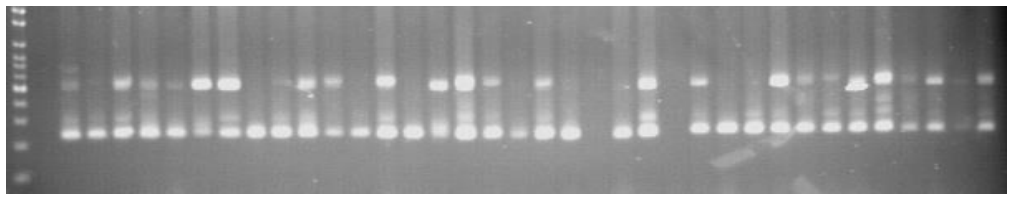

A00

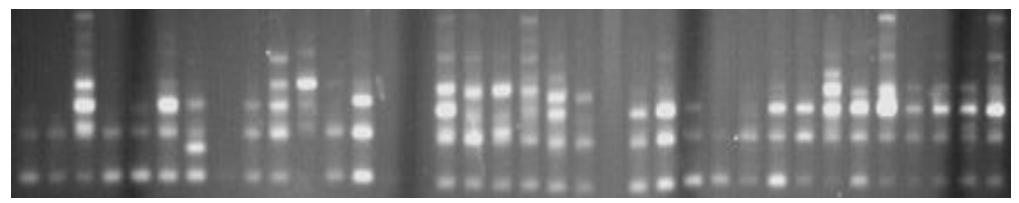

Figure 2. RAPD profiles of $B$. aegyptiaca collected from natural populations growing in different regions of Sudan (Representative DNA samples).

(BioCapt MW). The data was analyzed using NTSYS pc21 (version 2.11S). Dissimilarity coefficients were used to construct a dendrogram using un-weighted pair group method with arithmetic average (UPGMA) and sequential hierarchical and nested clustering (SHAN) routine.

\section{RESULTS AND DISCUSSION}

\section{Genomic DNA extraction protocol success and genetic polymorphism}

Over exploitation of forests for commercial purposes and other developmental activities have resulted in serious threat to tree species. Therefore, genetic diversity analysis is essential for both the long-term stability and short-term productivity of trees as diversity provides clues to the factors that direct the variation, inbreeding and gene flow.

The present investigation was undertaken to assess genetic diversity in Heglig (B. aegyptiaca) by using RAPD markers. In this study, the Ferreira and Grattapaglia
(1998) protocol modified for M. brauna was used for the DNA extraction and significant amount with good quality was obtained. This result suggests that this method could be used successfully in genetic diversity studies in Heglig using CTAB extraction buffer to ensure both quantity and purity. Similar results were obtained by other authors (Chiari et al., 2009; Ginwal and Mawrya, 2009).

Figure 2 shows a representative DNA samples. The DNA amplification and polymorphism generated among various genotypes of $B$. aegyptiaca using random primers are presented in Table 3. The ten primers generated a total of 57 DNA banding patterns with an average of 5.7 bands per primer. OPC-11 and OBA-13 gave the highest number of bands (8), whereas OPZ-04 showed the fewest number (2). There were 42 polymorphic bands. The polymorphism level ranged from 50 to $87.5 \%$ with a mean of $71 \%$. The high mean level suggests a high level of genetic diversity among populations. The same was observed in several other woody species for example those shown by Shah et al. (2008), Park et al. (2012) and Khamis et al. (2017). 
Table 3. RAPD primers used and their total number of bands, total number of polymorphic bands and polymorphic band percentage.

\begin{tabular}{lccc}
\hline Primer code & Total number of bands & Total number of polymorphic bands & Polymorphic band \% \\
\hline A00 & 7 & 4 & 57 \\
A06 & 5 & 4 & 80 \\
OPA-13 & 8 & 6 & 75 \\
OPB-07 & 7 & 6 & 85.7 \\
OPC-11 & 8 & 7 & 87.5 \\
OPO-02 & 6 & 5 & 83.3 \\
OPO-07 & 4 & 3 & 75 \\
OPU-03 & 2 & 1 & 50 \\
OPU-16 & 4 & 3 & 75 \\
OPZ-04 & 6 & 3 & 50 \\
Average & $\mathbf{5 . 7}$ & $\mathbf{4 . 2}$ & $\mathbf{7 1 . 7}$ \\
\hline
\end{tabular}

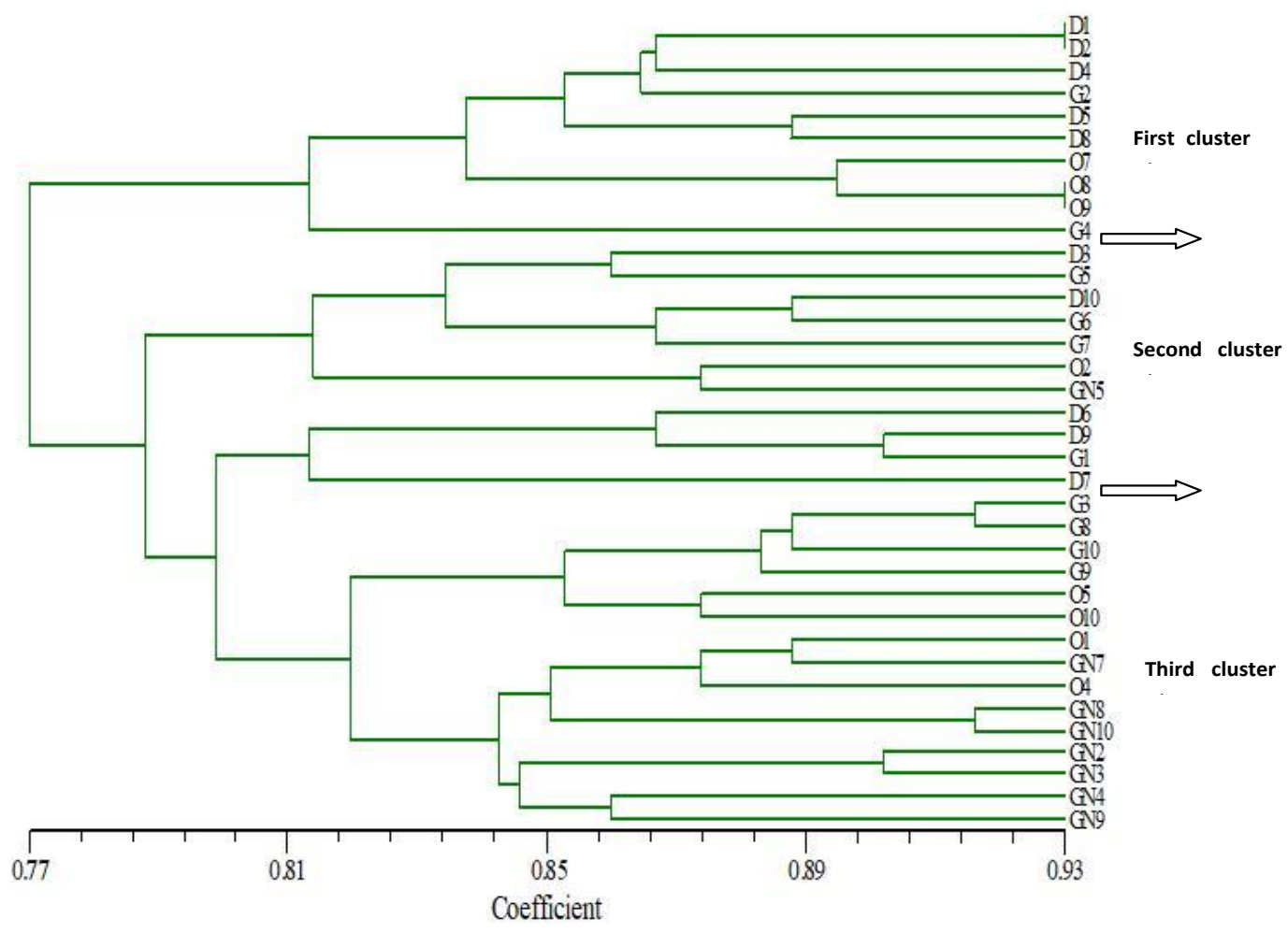

Figure 3. Cluster analysis derived from RAPD data to estimate the genetic dissimilarity for four populations of Balanites aegyptiaca growing in different regions of Sudan.

\section{Genetic relationship and cluster analysis}

RAPD analysis provides information that could help define the distinctiveness of species at a molecular level. Clustering components placed the 36 individuals from four provenances of $B$. aegyptiaca into three main clusters, using the software NTSYS-PC. The allelic diversity data were used for cluster analysis. 'Cluster Tree Analysis' sub-programme of the same software, revealed the genetic linkage and proximity among all the genotypes investigated. RAPD markers were used to produce a similarity matrix among individual species.

The dendrogram was constructed based on 57 fragments. Dissimilarity value varied between 77 and $93 \%$ (Figure 3). These wide ranges of genetic dissimilarity may emphasize the relatively wider diversity in gene pool of $B$. aegyptiaca.

A relatively high genetic diversity was obtained by Erfani et al. (2016) who tested the genetic variability among four species of Crataegus using morphological 
traits and RAPD markers.

The first cluster contained five families from Damazin (D) provenance which was equal to $50 \%$ of the total number of trees, three families from Obied (O) provenance that equal to $37.5 \%$ and two families from Gedaref $(G)$ that equal to $20 \%$. In this cluster, genotypes $\mathrm{D} 1$ and D2 and $\mathrm{O} 8$ and $\mathrm{O} 9$ were genetically most variable with genetic dissimilarity value of 0.93 . The second $50 \%$ of $D$ provenance was included in the second main cluster in addition to $30 \%$ from $G$ and $12.5 \%$ for both $O$ and $G N$. Seven families out of eight of GN provenance $(87.5 \%)$ were observed at the third cluster with 50 and $40 \%$ of $O$ and $G$, respectively. The distribution of $O, D$ and $G$ genotypes was clear. This may be due to effective gene flow among the three populations (marketing and movements) and limited gene flow with GN or through foraging. Arif et al. (2009) obtained 0.56 to 0.93 similarity coefficient value in tree Dalbergia sissoo. Genetic variations among sources may have been achieved by out crossing and also by the spread of the seeds through various geographical areas (Khamis et al., 2017). The clustering results might indicate that the geographical separation is more important in the genetic diversity analysis.

The genetic diversity detected in the present study could be due to distance factor as the genotypes studied were widely distributed in different agro-climatic regions. Moreover, the heterozygous and heterogeneous structure of Balanites population driven by its out breeding behaviour might be one of the reasons for high degree of polymorphism variability (Shashidhara et al., 2003).

\section{Conclusions}

The present study using RAPD displays some valuable information about Heglig diversity. In conclusion, RAPD markers are powerful tool for analyzing genetic relationships among B. aegyptiaca genotypes. Genetic diversity data obtained in this study can be further utilized in the conservation and development of improved varieties for further use in breeding programmes. Current study further concluded that the variability among and within sources indicates that seed movement between locations should be carefully examined so as to match planting site with seed source. Hitherto, this is the first report dealing with the pattern of molecular variation in those four provenances of $B$. aegyptiaca tree. As a result, the distribution of species is only related to its ability to disperse their pollen and/or seeds since no artificial acts are involved during the movement of wild seeds from one place to the other.

\section{CONFLICT OF INTERESTS}

The authors have not declared any conflict of interests.

\section{ACKNOWLEDGEMENT}

Authors gratefully appreciate financial and technical support from the Agricultural Research Corporation of Sudan.

\section{REFERENCES}

Abasse T, Weber JC, Katkore B, Boureima M, Larwanou M, Kalinganire A (2011). Morphological variation in Balanites aegyptiaca fruits and seeds within and among parkland agroforests in eastern Niger. Agroforestry Systems 81:57-66.

Abkenar AA, Isshiki S, Tashino Y (2004). Phylogenetic relationships in the true Citrus fruit trees revealed by PCRRFLP analysis of $\mathrm{cP}$ DNA. Science Horticulturae 102:233-242.

Agbidinoukoun A, Missihoun AA, Akonde P, Sagbadja HA, Agbangla C, Ahanhanzo $C$ (2017). Assessment for the Incidence of Number of Subcultures on Genotype Stability for In Vitro Plantlets of Yam (Dioscorea spp.) Using RAPD Markers. International Journal of Current Research in Biosciences and Plant Biology 4(4) ISSN: 23498080.

Arif M, Zaidi NW, Singh YP, Haq QMR, Singh US (2009). A comparative analysis of ISSR and RAPD markers for study of genetic diversity in shisham (Dalbergia sissoo). Plant Molecular Biology 27:488-495.

Artyukova EV, Kholina AB, Kozyrenko MM, Zhuravlev YN (2004). Analysis of genetic variation in rare endemic species Oxytropis chankaensis Jurtz. (Fabaceae) using RAPD markers. Russian Journal of Genetics 40:710-716.

Chiari L, Valle JVR, Resende RMS (2009). Comparação de três métodos de extração de DNA genômico para análises moleculares em Stylosanthes guianensis. Circular Técnica 36:1-6.

Elfeel AA (2010). Variability in Balanites aegyptiaca var. aegyptiaca seed kernel oil, protein and minerals contents between and within locations. Agriculture and Biology Journal of North America 1(2):170174.

Erfani MJ, Mozafari M, Fazeli A (2016). Genetic variation of some hawthorn species based on phenotypic characteristics and RAPD marker. Biotechnology Equipment 30:247-253.

Ferreira ME, Grattapaglia D (1998). Introdução ao Uso de Marcadores Moleculares em Análise Genética. 3aed. Embrapa-Cenargen, Brasília.

Garacia L, Jamilena M, Alvarez JI, Arnedo T, Oliver JL, Lozano R (1998). Genetic relationships among melon breeding lines revealed by RAPD markers and agronomic traits Theoretical and Applied Genetics 96:878-885.

Ginwal HS, Mawrya SS (2009). Evaluation and optimization of DNA extraction method for Dalbergia sissoo leaf. Indian Journal of Biotechnology 9:69-73.

Guerra JCV, Issa MRC, Carneiro FE, Strapazzon R, Moretto G (2010). RAPD identification of Varroa destructor genotypes in Brazil and other regions of the Americas. Genetics and Molecular Research 9:303308.

Holsinger KT, Lewis PO, Dey DK (2002). A Bayesian approach to inferring population structure from dominant markers. Molecular Ecolology 11:1157-1164.

Ibrahim MH, Hashim M, Nayan N, Omar Baki MH, Che Ngah MSY (2010). Relationship of Land Use on Temperature in Tanjong Malim, Perak. Journal of Techno-Social 2:47-68.

Idrees M, Irshad M (2014). Molecular markers in plants for analysis of genetic diversity: A review. European Academic Research 2(1):15131540.

Khamis G, Schaarchmidt F, Papenbrock J (2017). Genetic diversity among populations of the Xerophitic tree species Balanites aegyptiaca and its morpho-physiolgical responses to water deficiency. African Journal of Agricultural Research 12(35):3252-3269.

Liepelt S, Cheddadi R, de Beaulieu J, Fady B, Gömöry D, Hussendörfer E, Konnert M, Litt T, Longauer R, Terhürne-Berson R, Ziegenhagen B (2009). Postglacial range expansion and its genetic imprints in Abies Alba (Mill.): A synthesis from palaeobotanic and genetic data. Review of Palaeobotany and Palynology 153:139-149. 
Liesebach H, Götz B (2008). Low chloroplast DNA diversity in red dogwood (Cornus sanguinea L.). Silvae Genetica 57:291-300.

Magri D, Vendramin GG, Comps B, Dupanloup I, Geburek T, Gömöry D, Latałowa M, Litt T, Paule L, Roure JM, Tantau I, van der Knaap WO, Petit RJ, Beaulieu JL (2006). A new scenario for the Quaternary history of European beech population palaeobotanical evidence and genetic consequences. New Phytologist 171:199-221.

Missihoun AA, Sagbadja HA, Sedah P (2015). Genisshounetic diversity of Sorghum bicolor (L.) Moench landraces from Northwestern Benin as revealed by microsatellite markers African Journal of Biotechnology 14(16):1342-1353.

Muchigi A, Kadu C, Kindt R, Kipruto H, Lemurt S (2008). Molecular markers for tropical trees. A practical guide to Principles and Procedures. World Agroforestry Centre, Nairobi.

Mulcahy DL, Cresti M, Sansavini S, Douglas GC, Linskens HF, Bergamini MG, Vingani R, Pancadldi M (1993). The use randoum amplified polymorphic DNAs to fingerprint apple genotypes. Scientia Horticuturae 54(2):89-96.

Nejia Z, Icraf C, Badra B, Mahmoud G, Hassene Z, Adbelwashed G, Ahmed M (2007). Molecular base assessment of genetic diversity within Barbary fig (Opuntia indica) in Tunisia. Scientia Horticulturae 113:134-141.

Park JB, Park JG, Choo, GC, Ngondya, IB, Ibrahim RI, Shim SH (2012). Genetic diversity in six natural populations of Taxus cuspidate from Baekdu trail and Jeju Island in South Korea analysed by RAPD-DNA markers. Forest Science and Technology 8(4):210-214.

Rahman MM, Al Munsur M (2009). Genetic divergence analysis of lime. Journal of the Bangladesh Agricultural University 7(1):33-37.
Shah PK, Tripathi LP, Jensen LJ, Gahnim M, Mason C, Furlong EE, Rodrigues V, White KP, Bork P, Sowdhamini R (2008). Enhanced function annotations for Drosophila serine proteases: A case study for systematic annotation of multi-member gene families. Gene 407(12):199-215.

Shashidhara G, Hema MV, Koshy B, Farooqi AA (2003). Assessment of genetic diversity and identification of core collection in sandalwood germplasm using RAPDs. Journal of Horticultural Science and Biotechnology 78:528-536.

Sureja AK, Sirohi PS, Behera TK, Mohapatra T (2006). Molecular diversity and its relationship with hybrid performance and heterosis in ash gourd [Benincasa hispida (Thunb.) Cogn.]. Journal of Horticultural Science and Biotechnology 81:33-38.

Wei X, Cao HL, SH Y, Jiang WH, Ye X, Ge J, Li F (2008). Population genetic structure of Camellia nitidissima (Theaceae) and conservation implications. Botanical Studies 49:147-153.

Williams JG, Kubelik AR, Livak KJ, Rafalski JA, Tingey SV (1990). DNA Polymorphism amplified by arbitrary primers are useful as genetic markers. Nucleic Acids Research 18:6831-6535.

Zarek M (2009). RAPD analysis of genetic structure four natural populations of Taxus baccata from southern Poland. Acta Biologica Cracoviensia Series Botanica 51(2):67-75. 